\title{
NTUMBULUKO, THEOLOGY, AND ISSUES OF GENDER IN THE TSONGA WORLDVIEW: \\ TOWARDS AN AFRICAN WOMAN'S THEOLOGY OF LIBERATION IN MOZAMBIQUE
}

\author{
André Jonas Chitlango and Anthony Balcomb \\ School of Theology \\ University of KwaZulu-Natal
}

\begin{abstract}
Ntumbuluku is a word in Tsonga culture which is difficult to define but which depicts the essence of Tsonga culture with respect to the law and its requirements. It impacts on the whole of life, including issues of gender, and especially concerning the role and identity of women. How this impact takes place - whether to the detriment or advancement of women in Tsonga society - depends on how the concept is used. It can be both an unchangeable obstacle or hindrance to women's liberation and it can also be used to promote women's liberation. This essay is based on the conviction that Christian theology should be able to discern the difference between these two influences and build into Christian theology an understanding of ntumbuluko that contributes to the positive advancement of women in Tsonga society.
\end{abstract}

Vonani a ntumbuluko aku xonga ka wone!

A ntumbuluko ni mutchumo hikwayo;

Vonani a ntumbuluko aku xonga ka wone!

A ntumbuluko in mutchumo hikwayo.

See how beautiful ntumbuluko is!

Ntumbuluko and everything

See how beautiful ntumbuluko is!

Ntumbuluko and everything.

(Mavota, CD)

\section{Introduction}

Methodologically the issue of gender and (Protestant) theology in Africa have three main influences - the Enlightenment, Evangelical pietism, and culture. Inasmuch as Feminist theology has its origins in the Enlightenment values of equality, autonomy, human rights, and individualism, not to forget the legacy of secularism, it has had little direct influence in Africa. This is not to say that the feminist challenge has not been both provocative and inspirational for African woman theologians. Indeed it clearly has. Neither is it to infer that the Enlightenment tradition is the only place where the values outlined above are to be found. Indeed it isn't. Theological concerns around gender issues in Africa, however, have had to contend with the far greater influences of the European legacy of Evangelical Pietism ${ }^{1}$ and the African influences of

1. An attempt has been made by some Evangelical theologians to find a middle way between fundamentalist tendencies to stress biblical passages that place men in a dominant position over women and the feminist 
culture. The former has produced tendencies towards dualism and biblicism (as opposed to the secularism of theologies influenced by the Enlightenment) and the latter, with its traditional, and often oppressive, legacies concerning the status and identity of women in African society. This has meant that more liberative, or, more commonly, less oppressive, themes and trajectories within these traditions have had to be sought rather than taking for granted the existence of beliefs that have been shaped by the Enlightenment, which one can do within a Western context. The pietist legacy, for example, does not only offer the escapism of dualist solutions to the problem. It also offers forms of spirituality that might be harnessed in the cause of the liberation of women. Strong beliefs concerning, for example, equality "in Christ", unity "in the Spirit", and authority "in the Word" can be powerful motifs towards this end. The practice of such beliefs frequently manifests a far greater prominence to women than first appears to be the case. Similarly there are themes and trajectories within the dominant culture that have the same liberative potential. Indeed it is these that are the subject of this paper. Too often, however, the oppressive tendencies in the pietist legacy (for example Pauline appeals to the "place" of women in the church) are reinforced by similar tendencies in the dominant culture - for example taboos around women and their "place" in society and the divine order of the cosmos. Despite these difficulties contextual and liberative forms of African theology are being done in Africa with respect to issues of gender. Indeed it is the demand for contextuality that causes this theology to take into account an African and not a European worldview. If the interconnectdedness of the universe, the existence of spiritual entities, and communal notions of being (amongst other things), are not taken into account when confronting issues of gender and theology in Africa, then this theology can hardly be recognized as contextual. ${ }^{2}$

This paper attempts consciously to approach the issue of gender, therefore, from within the context of an African culture - more specifically the Tsonga culture. Even more specifically it attempts to employ a category that dominates the Tsonga worldview - the category ntumbuluku. Defining this category will not be easy as it is unique to Tsonga culture. However, one of the authors of this paper, Andre Chitlango, is a Tsonga himself and has been researching the subject of ntumbuluku from his Honours degree up to his present doctoral studies. The paper will therefore depend largely on his research thus far. What will hopefully become apparent is that ntumbuluku in Tsonga culture impacts on the whole of life, including issues of gender, and especially concerning the role and identity of women. How this impact takes place - whether to the detriment or advancement of women in Tsonga society, depends on how the concept is used. It can be both an unchangeable obstacle or hindrance to women's liberation and it can also be used to promote women's liberation. This essay is based on the conviction that Christian theology should be able to discern the difference between these two influences and build into Christian theology an understanding of ntumbuluko that contributes to the positive advancement of women in Tsonga society. In this way a contextual Tsonga theology of women can be constructed that is both cognizant and affirming of an essential aspect of the Tsonga worldview as well as critical of it. In other words when Christian theology is done around the concept of

tendency to dismiss the bible altogether as normative for gender relations. Ortlund, for example, attempts to demonstrate from the first three chapters of Genesis that "both male-female equality and male headship, properly defined, were instituted by God at creation and remain permanent, beneficent aspects of human existence" (1991:95).

2. Oduyoye, for example, in her Introducing African Women's Theology (2001) presents women's theological concerns as: (1) community and wholeness, (2) relatedness and inter-relationships, (3) reciprocity and justice, (4) compassion and solidarity (Oduyoye 2001:31-38). She argues that since African culture gives emphasis on relationships, culture has become a key issue in women's theology. The examination of the relationship between women and men led to a focus on religious anthropology. 
ntumbuluku within the context of issues of gender then it affords the opportunity of doing a theology that is both sensitive to and critical of culture - a theology that is at once enculturated and liberative. To do this kind of theology one would obviously need to be able to recognize the oppressive applications of ntumbuluku with reference to women as well as its liberative aspects so one can try to foreground and nurture the latter and transcend the former. Thus addressing the issue of ntumbuluku and gender affords the opportunity of doing an authentic contextual theology of liberation in every respect.

It must be stressed that this essay attempts merely to introduce the concept of ntumbuluku and suggest one or two ways in which it could be employed in the debate around theology and gender in Africa.

But first it is necessary to attempt a definition of the term.

\section{What is ntumbuluko?}

It is difficult to underestimate the pervasiveness and complexity of the influence of ntumbuluko in the Tsonga sector of Mozambican society. A profoundly resilient force, having survived the influences of Islam, Christianity (both Catholic \& Protestant) and Marxism it is as influential today in modern, democratic Mozambique as it was in the seventeen year civil war between Renamo and Frelimo. While the tendency of modernity is to disintegrate and compartmentalize all aspects of life, ntumbuluku integrates and unifies them under the rubric of tradition.

Although Tsongas hear and use the word ntumbuluku constantly it is not easily translatable into English because it has so many different uses in Tsonga languages and cultures (Xironga, Xishangaan and Xitshwa) and it has been adopted by other languages in southern Moçambique (Txitxopi and Gitonga). It has become a dominant concept of southern Moçambique, south of the Save River. The word has also made its way into the Bible in the five languages mentioned above. The biblical use of the word ntumbuluko is also complex and diverse, making its definition even more difficult.

The natural state of things, a creative power and principle, the power behind the beginning of things or that which cause anything to begin and/or exist, the created order of things, nature and life or vital force of life or being, laws of nature, culture, and society. All of these are involved in the meaning of ntumbuluko. In the Bible ntumbuluko is associated with:
a) biological birth (which is natural) (Jo 1:13; Ro 9:8);
b) heterosexuality (sex between men and women which is natural relations) as opposed to homosexuality (considered unnatural relations in the NIV) (Ro 1:26a, 26b, 27);
c) human nature as opposed to spiritual nature (Ro 7:14);
d) sinful nature (Ro 8:3, 5, 6, 7, 8, 9, 12, 13);
e) custom and natural law (Ro 11:24; 1 Co 11:24);
f) all things (Heb 1:3);
g) humanity (Heb 2:14); and instinct (Jude 10).

In Eph 2:3 and Gal 5:13, 16; ntumbuluko is identified with desires of the body (lust). In Gal 5:19, sexual immorality, impurity and debauchery; idolatry and witchcraft; hatred, discord, jealousy, fits of rage, selfish ambition, dissensions, factions and envy; drunkenness, orgies, and the like; are all listed as the works of ntumbuluko. Gal 6:8 warns that if anyone sows what pleases ntumbuluko, from ntumbuluko he / she will reap destruction; but the one who sows what pleases the Spirit will reap eternal life. ${ }^{3}$

3. In addition to old (1929) and new (1989) Tsonga versions and Xitshwa Bible (1972), we also used Xironga (2001), Txitxopi (1999) and Gitonga (1996) New Testaments. It is of importance to note that Gitonga spells 
In the Tsonga Bible, to create is $k u$ tumbuluxa, the creator is muntumbuluxi and nature, natural things, phenomena, and laws are all included under the rubric of ntumbuluko. Although ntumbuluko and muntumbuluxi (creator) come from the same root, suggesting any easy association of Christian Xikwembu (God) the creator (muntumbuluxi) with ntumbuluko in Tsonga cosmology is not so simple. Ntumbuluko is separate from Xikwembu. Xikwembu is an ancestor, a remote human being who was produced, sustained and recalled by ntumbuluko.

It can be seen from this short overview of the many and varied uses of the term that a definition is not easy. Attempts to use the term in translating Pauline theology of the "flesh" into Tsonga seem to heavily bias the meaning of the term toward a negative connotation. This is unfortunate because the term is probably far more neutral, or at least open to both positive and negative meanings, in its Tsonga use than its use here implies. To take such a concept out of the context of a worldview that is shaped by the one-ness of the universe, in other words a monistic worldview, and to use it to translate categories that have been shaped by a worldview that is essentially dualistic - the worldview of Paul and of Hellenism - is surely to end up with a distorted meaning. This erroneous translation reinforces the suspicion that Bible translation by missionaries, for example from the English into the vernacular, has in the past distorted original meanings with a view to demonizing indigenous religion and culture. ${ }^{4}$ When attempting a definition for the purposes of this paper, therefore, one would need to take this into account. We will define ntumbuluku as "Tsonga cultural and social norms, customs, traditions and institutions that constitute the basis of existence, self-understanding and identity in Tsonga society, in this case with respect to women".

In a telling Portuguese song a woman singer uses ntumbuluku thus:

Goza a vida como ela é... a tua maneira...

Ni na mahanyela ya mina, na wena una mahanyela ya wena

A tiro wa swilo loko u swivonela kule sha hlamalisa

Você não julga loko unga swi tive, a tiro wa swilo swa hlamalisa\{loko uswi vonela kule\}

Unga swi hleki loko swi ngahi ka wena, é natural (x)6

Você não julga a natureza é assim, vai lutando a vida é assim

I ntumbuluko lowu $(x 8)$

Toda gente conta naquilo que sabe, a vida é uma luta wa switwa.

A wunga yihli nyepi na wunga hi na matlhari

Não foge, vida é assim, é natural ( $x 8)$

I ntumbuluko lowo $(x 8)$

ntumbuluko "tumbunuko," Txitxopi sometimes spells "mtumbuluko" when speaking of nature or natural and "ntumbuluko" when speaking of the sinful nature and Xironga spells it "ntumbuluku."

4. "The best example to look at is the Bible, which was translated during the nineteenth century, with great dedication and eagerness, into several languages of the South. As you know, not only were these languages powerless, but their speakers were also illiterate, with no written tradition. Although perhaps intended otherwise, these Bible translations are seen today as a form of colonization in the guise of conversion and civilization. It was how Western values gained access to closed communities, in order to destroy what were regarded as primitive traditions. In writing them down, the missionaries adapted the languages, sometimes with scandalous distortions, in order to convey the Christian message. This process trapped languages in structures that can at best be described as hybrid: On the one hand, the language as people use it is oral and flexible and 'pagan'; on the other hand, it is written down, and inflexible, and the carrier of the 'highest and best of Western values" (Antjie Krog: A Change of Tongue, 2003:272). 
Mahanyela mahibinza hikweru, ko hambana matirela (decisão) ya hina

I ntumbuluko unga ali leswo intumbuluko

Você não foge a natureza, a vida é assim

É natural (x8)

Intumbuluko lowo $(x 8)$

Enjoy life as it is ... in your own way ...

I have my own way of living, you have also yours;

It is always like that; when one sees things happening.

In someone's life from a distance, it is fun.

Don't judge what you don't know,

Things look fun from far.

Don't laugh when things happen to others, it is natural (x 6)

Don't run away, nature is like that, go striving, life is like that

This is ntumbuluko (x8)

Everyone count on what they know, life is struggle you know.

You cannot fight a war without weapons;

Don't run away, life is like that;

It is natural (x8)

This is ntumbuluko (x8)

Life is heavy to everyone, what differs are our ways of working, or doing things

And making decisions, it's ntumbuluko.

Don't reject this is ntumbuluko.

Don't run away from nature, life is like that,

It is natural (x8)

This is ntumbuluko (x8)

(M'boa, CD)

In this song Rosália M'boa, a well known Mozambican singer, answers her critics and justifies the way that she chooses to live her life. All that she does and is, she says, is according to the natural law of ntumbuluku. Ntumbuluko is inescapable and her actions should not be condemned because she is doing what is according to it. Her lifestyle, way of living, what happens to her (normal and natural things), the way she earns her living and how she goes about equipping herself in life are all to do with ntumbuluko and she cannot run away from it but must simply accept it and fight her way and survival through the course prescribed for her by ntumbuluko.

In this song the word is quite clearly being used to create some ambivalence to the concept of tradition. She concedes that there is a natural order of things but is so bold as to suggest that the lifestyle she has chosen is that natural order and she does not need the criticism and judgmentalism of others who think differently. The conservative underpinning of the term is reinterpreted in a way that gives legitimacy to the way that the she herself understands what is "natural" in life. She concedes that this might be different to the way that others see it, but she is determined to define for herself what is good for her life.

There is, therefore, an incipient rebelliousness here.

In another song a young man uses the word ntumbuluko to denote a tradition or a mindset that needs to be "killed" because it is destructive. The tradition that is being 
referred to here is the one that imposes lovolo (ilobolo) and justifies it as ntumbuluko. He is calling for the killing of this "ntumbuluko" so that an ntumbuluko that is dignifying to women and serves to build the nation can remain.

For Ndzukule, one of our informants, ntumbuluko "is the greatest thing, the thing that is above everything on earth, to everyone whoever exists" (Chitlango 2002:41). Ntumbuluko "cares" about life and death and that those who follow ntumbuluko have life. "Ntumbuluko upholds my family...the woman I married and my child's family. Ntumbuluko is a fence around the home" (Chitlango 2002:41). He divides ntumbuluko into three different categories - that to do with the national or communal, that to do with the tribal, and that to do with the clan and the family.

Ntumbuluko is built by the law ${ }^{5}$ given to people. When God made humans, he gave the human a friend, with her moods and ways of living, this was a friend to stay with. With this friend, God gave the man the law to live by. In this law is the calabash of life. If you change this you have done wrong / sinned.

And again:

Ntumbuluko is the pot. It is the law in which the whole of human life exists. Ntumbuluko is the foundation ... Any, each and every law is based on this foundation ... Ntumbuluko is the firm rock or cornerstone because it holds everything together ... (Chitlango 2002:43)

Ntumbuluko here is presented as the divine law, which regulates life and as such must never be changed. If one wants to live, one dare's not disturb it. This understanding of ntumbuluko is close to that of the second song. One must just follow and obey ntumbuluko and live, or disobey, or try to change it, and die. The death referred to here is the phenomenon of "adult instant death" by disease caused by breaking ntumbuluko laws. These laws are generally ritual laws for protecting men from the ills of women's impurities.

A Tsonga academic defined ntumbuluko as:

Everything we do that deeply touches our birth life (natural or traditional life). We can say that ntumbuluko is a power that we do not see (an invisible power), it is a power that is capable of changing / turning or converting our lives. This power can spoil or break down our lives; it can straighten or fix up our lives. All this happens if we believe in its power.

From these sample meanings of ntumbuluko one can see that there are both positive and negative connotations associated with the concept. It is both a creative and constructive power to be celebrated; an inescapable power of nature; a law of life; the foundation of ritual, tradition, and custom; the power behind the beginning of life; the invisible power operating through the ancestors and controlling the course of human life for good or ill; and so on.

To harness the positive and negate the negative aspects of ntumbuluku in women's development there is the necessity of understanding further these different roles.

\section{Oppressive uses of ntumbuluko}

There are many aspects of ntumbuluku which are oppressive to women. Widowhood rituals, for example, involve sexual "cleansing" which means that the woman (widow) must have sex with all her brothers-in-law and the father-in-law during one night after the death of her husband. This could be described as nothing less than ritual gang rape. Other laws of ntumbuluko relate to menstruation. Some of our informants (Mangwele, Nhanombe and Dule) indicated that in their churches women are impure during their menstrual periods and

5. Ntumbuluko is the law given to humans because of the impurities of women so that it may regulate man's relationship with the woman, protecting the man from the deadly infections of the woman's impurity. 
cannot partake of the Holy Communion. For Nhanombe: "According to the doctrine of the Lord's Supper, to this day, mature Christians put on Christlikeness. It is taught that a woman going to partake of the Supper, must not be in her period...". This is linked with female ordinands who will inevitably have to administer communion and preach during their periods of menstruation. This is obviously behind some people complaining about an "invasion" (an obvious exaggeration) of female pastors to pastoral office in the United Methodist Church in Moçambique.

If one follows our laws of ntumbuluko and the Holy Scriptures, I do not believe that a woman is allowed to climb to the pulpit if she is running [menstruating] ... A woman must not climb to the pulpit while she is running. She must not meet with other people, she is impure. But today a woman is pastor, a woman is superintendent and she is to serve the Supper, but she is running. My head is starting to ban. What we devalue is what takes our power away!

Here is a fairly obvious admission that what is truly at the heart of this age old concern about the ritual impurity of women is the need for males to have hegemony in ritual practices. This does not alter the fact that the taboos surrounding women in this condition are legion. A woman in her period must not even handle food or cook, she must not put water for the husband to bath, nor touch his clothes and bed. She must sleep in a separate place and never walk close to the bed or sleeping place of the husband. If she fails to do this, the husband will either contract a hernia or suffer impotency. Touching of the clothes may also destroy the prophetic power of the husband if he is a prophet in the African tradition. Many other misfortunes are blamed on women. Most human health problems are blamed on women who do not following ntumbuluko. One of my informants blamed the disrespect of ntumbuluko for present men's short life-span. Longevity is achieved through women's strict observance of ntumbuluko. Any attempt on the side of women to overlook any ntumbuluko stipulated law or ritual, is regarded as dangerous to men's well-being and survival as well as that of children.

This negative view of women in ntumbuluko is closely associated with the concept of the woman as wife. It is not possible in the Tsonga language to separate the notion of "woman" from the notion of "wife". 6 The idea of a woman having an individual identity separate from any association with a man is therefore difficult. There are two possible ways of moving away from this state of affairs. One is to identify other identities that women may have in traditional Tsonga society that lend them more status and dignity as individuals and the other is to afford them the opportunity of attaining more education and therefore more autonomy. The latter will inevitably mean the weakening or at least the relativizing of traditional values and therefore also of the influence of ntumbuluku in their lives. For those who do not have such opportunities the former scenario remains the best option.

\section{Liberating uses of 'ntumbuluku'}

One such identity in Tsonga society is that of the mother. Tsonga people are very attached to the mamani/manana or "mother" but oppressive of the wansati or "woman." Privileging the former over the latter will mean upgrading the status of a woman from being an

6. Unlike the Indo-European languages (English and Portuguese) which distinguish between the words female / femia, woman/mulher and wife/esposa as well as male/macho, man/homen, and husband/marido, Tsonga has only one word for the three - "nsati" (wife) and "nuna" (husband). One produces artificial differences by adding a prefix to the root. Xinsati (female, literally "that of wife"), wansati (woman, literally "of wife") and nsati (wife); Xinuna (male, literally "that of husband"), wanuna (man, literally "of husband”) and nuna (husband). 
appendage of a man to a co-creator of humankind with God. The concept of motherhood that should be promoted is not only biological in nature. In the concept of motherhood we have something far more than the ability to make babies - which is something, in any case, that women once again need men for. But if the notion of motherhood is extended to include nurturing, sustaining, and imparting life not only in the physical but also the spiritual, emotional, and intellectual senses of the word then we indeed have something profound indeed. As Mercy Oduyoye has said: "I have no biological children ... I am not a mother but I have children" (Oduyoye 2002:57). Oduyoye distinguishes between biological motherhood and a mothering principle in human relationships which all women in Africa exercise against all odds (Oduyoye 2002:58).

There are two sayings that reveal this deep attachment of the Tsongas to the "mother:"

"A vale la mamani a li na thumba (the mother's breast has no sores or cancer)."

"A ve yoo mamani wa mungana (No one ever cries by invoking someone's mother)."

The first saying indicates that in Tsonga culture one depends on and appreciates the "mother" in whatever condition she might find herself. If the "mother's" breast has sores, others might laugh and reject her, but her baby child, for whom she is mother, will suck those breasts with smiles of gladness and gratitude. The baby has no other mother and never will have. The second saying refers to the fact that Tsonga people, whenever crying in pain or panic, exclaim "mamaneee" or "mamani wa minooo" ("mother" ... or my "mother" ...). In such an instantaneous cry they never call father or even God. Any Tsonga in true agony will cry "mamaneee" even if the intended recipient of the cry is God; God is called "mother" in such circumstances.

But women in Tsonga society are not only wives and mothers. There is also a leadership role for women of a more obvious kind in Tsonga traditional society. In answer to the question "What does ntumbuluko mean for women in Moçambique?" posed at a Baptist Pastors Conference the following responses were made:

Ntumbuluko does contribute to women's development. Women or masungukati (women elders) were involved in everything in the past. A man without wife was nothing in ntumbuluko. Women were given better and nice parts of meat, this reveals how important women were in ntumbuluko (Madime 2003, interview).

Masungakati or masungalakati are women who assume various positions of responsibility in ntumbuluko governing and administrative systems. They act as advisers, counsellors for the kings, judges, and prosecutors and lawyers in the royal court. The majority of problems that pass through the traditional court are of a social nature and they involve women directly and indirectly. In such cases, women are the lawyers for younger women to help them face men, and other women do the detailed prosecution and cross-examining as well as passing judgement.

In these interviews we drew our informants' attention to the term nkosikazi which some of them used. This term, which is usually used to designate a wife, literally means "female king." We also pointed out that the term for the male head of family (mulumuzana) does not come from the same root "nkosi" (king) and that it does not bear royalty. When we asked what the implication of all this is in terms of ntumbuluku, they all agreed that the term "nkosikazi" accorded the highest honour and respect in ntumbuluko to women, which is reserved for royalty. But they were not happy that ntumbuluko does not accord them or give them sharing in the woman's royalty. They felt that that could diminish their importance before women or their wives. 


\section{Conclusion}

Women's identities in African culture seem inevitably to be defined in terms of the relationships that they have in the communities in which they have their being. In other words, it appears impossible to conceive of women with an autonomous identity where they are able to exist as individuals outside of other relationships. In Western culture the autonomisation of the individual means that identities are able to have meaning outside of specific relationships. This is not the case in African cultures where identities continue to be defined in communal (read "relationship") terms as opposed to individual terms. This essay has attempted to demonstrate that in spite of many obstacles in the way of women's liberation in some African cultures - in this case the Tsonga - the relationships defining the status of women do not always relegate them to an inferior position. On the contrary there are instances where women are accorded higher, albeit still different, statuses, than men. This does not mean, however, that these statuses are granted to them - as our research indicated that in spite of space being made for women in this way men continue to dominate and oppress women and do not want their positions to be threatened. Focusing on the varied understandings with respect to gender in an indigenous concept such as ntumbuluku, however, may open the way for Tsonga traditionalists to review, and hopefully reconsider, their prejudices with respect to women. This may be small consolation for many women who are only too aware of their demeaned status in their culture. But for women who still, for one reason or another, are unable to function except within their cultures, it may offer some hope. The other alternative of modernization the Enlightenment way continues, of course, to be another alternative. It is doubtful, however whether the beliefs surrounding ntumbuluku will be replaced by modernity. The most one can expect for the foreseeable future is some degree of modernization of the term itself.

\section{BIBLIOGRAPHY}

Bilezikian, G 1985. Beyond Sex Roles: A Guide for the study of Female Roles in the Bible. Grand Rapids: Baker Books.

Calvin, J 1948. Commentary on the Epistles of Paul the Apostle of the Corinthians. Translated by J Pringle. Grand Rapids: Eerdmans.

Chitlango, AJ 2002. Ntumbuluko and Christian Faith: The Encounter of Gospel and Culture in the Interaction of Christian and Tsonga Theoretical Constructs of Reality in Southern Mozambique. Unpublished MTh thesis (upgraded to PhD), University of Natal, Pietermaritzburg.

Conjunto Guezi 2001. Natureza. CD copied from Radio Moçambique. Maputo, Moçambique. Cumbane, M 2003. Interview with author. Ponta D’Ouro, Moçambique.

Frame, JM 1991. "Men and Women in the image of God", in Piper, J \& Gruden, W (eds.), Recovering Biblical Manhood and Womanhood: A Response to Evangelical Feminism, 225-232. Wheaton: Crossway Books.

Johnson, G 1991. "The Biological Basis for Gender-Specific Behavior”, in Piper, J \& Gruden, W (eds.), Recovering Biblical Manhood and Womanhood: A Response to Evangelical Feminism, 280-293. Wheaton: Crossway Books.

King, J (ed.) 1994. Feminist Theology from the Third Word: A Reader. London and New York: SPCK and Orbis Books. 
Kinyange, P 1994. "Factors Contributing to Malnutrition in Urban Areas", in African Women: Our Burdens and Struggles, 39-44. Johannesburg: Institute for African Alternative.

Krog, A 2003. A Change of Tongue. Random House, Parktown.

Luther's Works 1955. American Edition.

Macamo-Chitlango, RT 2003. Interview with author. Pietermaritzburg, South Africa.

Madime, J 2003. Interview with author. Ponta D’Ouro, Moçambique.

Matusse, B 2003. Interview with author. Ponta D'Ouro, Moçambique.

Mavota, I 2001. Tudo Feito P'elo Criador. CD copied from Radio Moçambique. Maputo, Moçambique.

Mazive, A 2003. Interview with author. Ponta D’Ouro, Moçambique.

M'boa, R 2001. É Natural. CD copied from Radio Moçambique. Maputo, Moçambique.

Njoroge, NJ \& Dube, MW (eds.) 2001. Talitha Cum! Theologies of African Women Pietermaritzburg: Cluster.

Oduyoye, MA \& Kanyoro, MRA (eds.) 1992. The will to arise: Women, tradition, and the Church in Africa. New York: Orbis Books.

Oduyoye, MA 2001. Introducing African Women's Theology. Sheffield: Sheffield Academic Press.

Oduyoye, MA 2002. Beads and Stands: Reflections of an African Woman on Christianity in Africa. Yaoundé and Akropong-Akuapem: Editions Clé and Regnum Africa

Ogebe, MB 1994. "Social Injustice", in Mhugua, J (ed.), Our time has come. Grand Rapids: Baker, 61-66.

Ortlund, RC 1991. "Male-female Equality and Male Headship: Genesis 1-3", in Piper, J \& Gruden, W (eds.), Recovering Biblical Manhood and Womanhood: A Response to Evangelical Feminism, 95-112. Wheaton: Crossway Books.

Phiri, IA; Govinden, DB \& Nadar, S (eds.) 2002. Her-Stories: Hidden Histories of Women of Faith in Africa. Pietermaritzburg: Cluster Publications.

Piper, J \& Gruden,W 1991. Recovering Biblical Manhood and Womanhood: A response to evangelical Feminism. Wheaton: Crossway.

Romba, RY 1994. "Women in Society”, in Mbugua, J (ed.), Our Time has Come, 104-110. Grand Rapids: Baker Book House.

Russell, LM \& Clarkson, JS (eds.) 1996. Dictionary of Feminist Theologies. Louisville: Westminster John Knox Press.

Ruether, RR 1985. Womanguides: Readings toward a Feminist Theology. Boston: Beacon Press.

Spencer, AB 1985. Beyond the Curse: Women Called to Ministry. Nashville: Thomas Nelson.

Schreiner, TR 1991. "The Valuable ministries of Women Leadership: A Survey of Old Testament and New Testament Examples and Teaching" in Piper, J \& Gruden, W (eds.), Recovering Biblical Manhood and Womanhood: A Response to Evangelical Feminism, 209-224. Wheaton: Crossway Books.

Vine, WE 1985. An Expository Dictionary of New Testament Words. Nashville, Camden, and New York: Thomas Nelson Publication.

Wesley, J 1754. Explanatory Notes upon the NT. Naperville: Allenson.

Weinrich, W 1991. "Women in the history of the Church: Learned and Holy, but not Pastors", in Piper, J \& Gruden, W (eds.), Recovering Biblical Manhood and Womanhood: A Response to Evangelical Feminism, 263-279. Wheaton: Crossway Books. 